\title{
Accumulation of lead in the muscle of brackish water fish (Boleopthalmus dussumieri)
}

\author{
Ranjana Surana*, Mohini Gadhia and Ekhalak Ansari \\ Department of Aquatic Biology, Veer Narmad South Gujarat University, Surat-395007 (Gujarat), INDIA \\ *Corresponding author. E-mail: ranjanajain27@yahoo.com \\ Received: February 28, 2015; Revised received: June 30, 2015; Accepted: August 18, 2015
}

\begin{abstract}
Lead is highly toxic, impairing biological functions of aquatic animals. In vitro, static test was performed to find out the accumulation of lead in the muscle of brackish water fish (Boleopthalmus dussumieri). Fish were maintained in experimental aquaria with lead nitrate solution having known lead concentration of 1.48 and $14.8 \mathrm{mg} /$ I, respectively. The experiments were performed in triplicate. Two fishes from each exposed aquarium were sampled on zero hour, 96 hours and 192 hours. Muscle was removed and processed prior to analysis of lead concentration by Atomic Absorption Spectroscopy. The amount of lead accumulated in muscle of experimental fish increased steadily with the period of exposure. The lead accumulated in fish muscle was $29.60 \pm 6.62 \mu \mathrm{g} / \mathrm{g}$ at 96 hours of exposure and accumulated up to $72.48 \pm 14.18 \mu \mathrm{g} / \mathrm{g}$ in 192 hours of exposure period at the highest concentration. Significant relationship between accumulation and exposure period as well as exposed concentration $(p<0.05)$ at the significance level of $95 \%$ was recorded. The present study indicated that the fishes living in mudflats of brackish water bodies receiving industrial as well as anthropogenic waste water containing an assortment of heavy metals can accumulate them in considerable concentrations.
\end{abstract}

Keywords: Boleopthalmus dussumieri, Exposure, Heavy metals, Uptake

\section{INTRODUCTION}

Bioaccumulation refers to the accumulation of a substance in the body of organisms without being metabolized and assimilated. It results in an increase in the concentration of a chemical in a biological organism over time, compared to the chemical's concentration in the environment. Heavy metals are non-biodegradable and form part of environmental pollutants in which elevated levels threat to human health through food chain (Goodwin et al., 2003; Rauf et al., 2009). The toxic actions of heavy metals occur due to bioaccumulation and biomagnifications of the elements in the tissues of living organisms. Heavy metals are also preferentially accumulated by different organs of the body (Vinodhini and Narayanan, 2008; Rauf et al., 2009). Various metal ions get biologically magnified when taken up from the surrounding water in their various tissues as they grow. This uptake and bioaccumulation is well documented in skin, gills, stomach, muscles, intestine, liver, brain, kidney and gonads but their main target organs are liver, kidney and muscles depending on the exposure concentration and time (Allinson et al., 2002; Spokas et al., 2006).

Lead, a non-essential and toxic metal, is released into the aquatic environment by industrial sources such as chemical and fertilizer industries, refining of ores, the plating process, lead battery production, coloured inks and paint preparation. Lead constitutes an important component of wastes discharged from industries to which aquatic animals especially fishes are exposed. Lead and other trace metals have high affinity for animal tissues where they are concentrated to varying levels (Huang, 2003; Martinez et al., 2004).

The positive correlation between the concentration of metals in the aquatic environment and the tissue of the fish often pose serious health problems to fish consumers especially man (Bu-Olayan and Thomas, 2008). Consumption of fish with high amount of lead is a major route of human exposure to lead. Fishes exposed to high levels of lead exhibit a wide range of effects including behavioral deficits, cancer, disease resistance, muscular and neurological degeneration and destruction, growth inhibition, mortality, reproductive problems, may cause structural lesions and functional disturbances and paralysis (USEPA, 1976; Rademacher et al., 2003).

Mudskipper (Boleopthalmus dussumieri) is distributed in the mudflats of Tapi estuary in Gujarat. They are the prey for many predators and also consumed by humans, therefore it is essential to evaluate the extent of bioaccumulation of metals in this fish. The main routes of accumulation of metals by fish are through the gills, skin and food (Hein et al., 1993). The objective of this study was to determine the role of $B$. dussumieri as a bioaccumulator of heavy metal that can be included as a biomonitoring tool to determine the metal level in mudflats of estuary. 


\section{MATERIALS AND METHODS}

Mudskipper (Boleopthalmus dussumieri) was selected for the study. It inhabits the tidal mudflats of Tapi estuary. It is commercially important as a cheap source of food and ecologically important as an indicator of heavy metal pollution. The size and weight of fishes used during experiment were about $6 \pm 1 \mathrm{~cm}$ and $8 \pm 1$, gm respectively. Lead standard stock solution was prepared by dissolving $1.599 \mathrm{~g}$ of lead nitrate in $10 \mathrm{ml}$ of diluted nitric acid (1: 10) and deionized water was added to make the volume of $1000 \mathrm{ml}$. One $\mathrm{ml}$ of this solution contained $1 \mathrm{mg}$ of lead $(\mathrm{Pb})$. Required test solutions for the study were prepared by dilution of stock solution. Bioaccumulation test was carried out in the laboratory condition in glass aquaria following the method described by FAO/SIDA (1983) and USEPA (2002).

Fishes were maintained in $15 \%$ saline water prepared from tap water by adding sodium chloride in glass aquaria at room temperature. Water was changed every second day. Fishes were acclimated to this condition for one week before being exposed to experimental conditions. They were not fed twenty four hours prior and during the experiment. Static test was performed. Six glass aquaria each of 05 litre capacity were set up in triplicate. The known concentrations of lead $(\mathrm{Pb})$ in the water of experimental aquaria were $1.48 \mathrm{mg} / \mathrm{l}$ and $14.8 \mathrm{mg} / \mathrm{l}$ respectively .One litre of required concentration of treatments each containing six fishes were maintained in a glass aquaria. All the aquaria were kept at room temperature, covered with net to prevent the escape of fishes and well aerated with the help of aerators. Fish and water sampling in the experimental aquarium was done on 0 hour, 96 hours and 192 hours respectively from all treatments. Two fishes from each aquarium were sacrificed and muscles were removed for sample processing. All the experiments were repeated thrice. The samples were allowed to oven dry and acid digested for lead analysis by AAS following standard methods (Hoffman, 1996).

The obtained data were statistically analyzed using t-test to determine significant difference between accumulation, exposure period and exposed concentrations with the help of SPSS 16.0 computer statistical software package.

\section{RESULTS}

The concentration of prepared lead solution $(1.48 \mathrm{mg} / 1$ and $14.8 \mathrm{mg} / \mathrm{l}$ ) analyzed at 0 hour (immediately after experiment) was found to have lead concentration $1.47 \mathrm{mg} / 1$ and $14.7 \mathrm{mg} / 1$, respectively. Lead was not detected in the fish at 0 hour. Accumulation of lead in muscles of fish $B$. dussumieri exposed to known concentrations at different periods is presented in Fig. 1. The amount of lead accumulated in muscles of tested fish increased steadily with period of exposure. Concentration of lead in muscle of fish was found to be concentration and exposure period dependent .The fish accumulated up to $72.48 \pm 14.18 \mu \mathrm{g} / \mathrm{g}$ at the highest concentration in 192 hours of exposure period (Fig. 1). Statistical analysis (t-test) showed significant relationship between accumulation, exposure period, as well as exposed concentrations $(p<0.05)$ at the significance level of $95 \%$ (Table 1).Significant difference was noted for lead concentrations in fish muscles between 0 hour- 96 hours,0 hour - 192 hours and 96 hours- 192 hours of exposure period at both concentrations of lead solution (Table 1).

\section{DISCUSSION}

The lead accumulated in B. dussumieri exposed to different concentrations of lead nitrate solution was found to be a function of concentration and duration of exposure. At $1.47 \pm 0.043 \mathrm{mgl} / 1$ the lead uptake was found to increase from $18.09 \mu \mathrm{g} / \mathrm{g}$ (dry weight) in 96 hours to $23.86 \mu \mathrm{g} / \mathrm{g}$ in 192 hours. At the highest concentration there was increase from $29.60 \pm 6.62$ in 96 hours to $72.48 \pm 14.18 \mu \mathrm{g} / \mathrm{g}$ in192 hours. This was found to be statistically significant $(\mathrm{P}<0.05)$. The quantity of metal accumulated has been reported to be directly related to the concentration to which the organisms are exposed and the period of exposure (Otitoloju, 2001; Kamaruzzaman et al., 2010). Similar increases in other metals burden with increase in exposure concentrations have been reported by different workers like Kotze et al., 2006 ; De-Forest et al., 2007; Narges et al., 2012.

Kotze et al. (2006) ; Senthil et al. (2008) found increased concentration of metals through bioaccumulation with the increase in effluent concentration, and bioaccumulation of the analyzed metals was significantly higher in the body muscle at higher concentrations. According to the work of Al-Nagaawy (2008), lead residues in the muscles recorded a significant increase than control in fingerlings exposed to both lead concentrations (12 and $6 \mathrm{mg} / \mathrm{l}$ ) during accumulation period. Highest lead concentration $(132.42 \pm 7.62 \mathrm{mg} / \mathrm{kg})$ was recorded after 4 weeks of exposure to $12 \mathrm{mg} \mathrm{Pb} / \mathrm{l}$. Victor et al (2012) found that Clarias gariepinus exposed to the lowest $(0.032 \mathrm{mg} / \mathrm{L})$ and highest $(0.180 \mathrm{mg} / \mathrm{L})$ concentration of lead solution accumulated 12.63 and $33.49 \mu \mathrm{g} / \mathrm{g}$ lead after eight weeks of exposure for the whole fish. They concluded that the lead burden in C. gariepinus exposed to different concentrations of lead nitrate solution was found to be a function of concentration and duration of exposure.

Above studied works supports the present study, where the accumulation of metal has been reported to be directly related to the concentration to which the organisms was exposed and the period of exposure . According to Daramola and Oladimeji (1989), the general increase observed in the level of lead with increased exposure period might be due to increase in the level of low molecular weight metal-binding proteins such as hepatic metallothionein. Such an 
Table 1. Statistical analysis for accumulation of lead in fish muscle during experiment.

\begin{tabular}{ccc}
\hline \multirow{2}{*}{ Exposure period of fish } & $\begin{array}{c}\text { Concentration } \\
\mathbf{( 1 . 4 8 m g / L )}\end{array}$ & $\begin{array}{c}\text { Concentration } \\
(\mathbf{1 4 . 8} \mathbf{~ m g} / \mathbf{L})\end{array}$ \\
\cline { 2 - 3 } & & $\mathbf{P}$ values \\
\hline 0 hour-96 hours & 0.045 & 0.017 \\
0 hour-192 hours & 0.018 & 0.013 \\
96 hours-192 hours & 0.014 & 0.064 \\
\hline
\end{tabular}

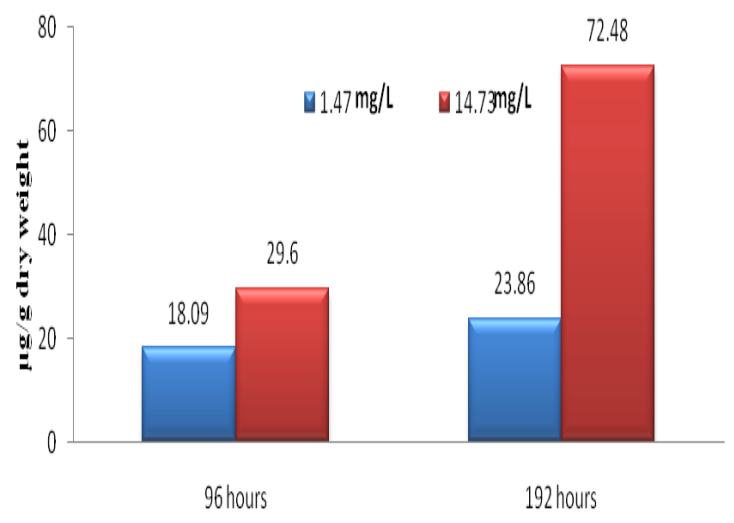

Fig. 1. Bioaaccumulation of lead in fish muscles at different exposed concentrations and period.

increase might be a response by the fish to remove lead from the circulation and hence reduce lethal effects. Low molecular weight metal binding proteins are known to play a significant role in the detoxication of heavy metals. In present study also increase in accumulation was observed with increase in exposed concentration.

\section{Conclusion}

It was concluded that fish, $B$. dussumieri, can accumulate metals in higher concentrations than the quantity in its surrounding environment and can have toxic effects in living organisms depending on fish for food. Thus, $B$. dussumieri can be taken as a bioindicator tool for evaluating metals in the aquatic environment.

\section{ACKNOWLEDGEMENT}

The author (Ranjana Surana) is thankful to UGC for awarding Junior research fellowship under the scheme Junior research fellowship for foreign nationals. The authors are thankful to Dr. Gaurang Rami, Professor, Department of Economics, Veer Narmad South Gujarat University for his valuable guidance.

\section{REFERENCES}

Allinson, G., M. Nishikawa, S.S. De Silva, L.J.B. Laurenson and K. De Silva (2002). Observation on metal concentrations in tilapia (Oreochromis mossambicus) in reservoirs of South Sri Lanka. Ecotoxicol. Environ. Safety, 51: 197-202

Al-Nagaawy, A.M. (2008). Accumulation and elimination of copper and lead From O. Niloticus fingerlings and consequent Influence on their tissue residues and some biochemical parameters, $8^{\text {th }}$ International Symposium on Tilapia in Aquaculture, 431-445

Bu-olayan, A.H. and Thomas, B.V. (2008). Trace metals toxicity bioaccumulation in Mudskipper Periophthalmus waltoni Koumas 1941 (Gobiidae: Perciformes). Turk. J.Fish. Aquat. Sci., 8: 215-218.

Daramola, J.A. and Oladimeji, A.A. (1989). Accumulation of copper in Clarias anguillaris and Orechromis niloticus 1. Water, Air and Soil Pollution, 48: 457 - 461

De-Forest, D.K., Brix, K.V. and William, J.A. (2007). Assessing metal bioaccumulation in aquatic environments. The inverse relationship between bioaccumulation factors, trophic transfer factors and exposure concentration. Aqua. Toxicol., 84:236-246.

FAO/SIDA (1983). Manual of methods in aquatic environment research part 9. Analysis of metals and organochlorines in fish. FAO Fish Tech. Pap. (212) 32.

Goodwin, T.H., Young, A.R., Holmes, M.G.R., Old, G.H. and Hewitt, N. (2003). The temporal and spatial variability of sediment transport and yields within the Bradford Beck Catchment, West Yorkshire. Sci. Total Environ., 314(a). 316:475-494.

Hein duPreez, H., vanRensburg, E. and vanVuren, J.H.J. (1993). Preliminary laboratory investigation of the bioconcentration of zinc and iron in selected tissues of the banded Tilapia, Tilapia sparrmanii (Cichlidae). Bulletin of Environment Contamination and Toxicology, 50: 674-681.

Hoffman, G.L. (1996). Methods of analysis by the U.S. Geological Survey National water quality laboratory preparation procedure for aquatic biological material determined for trace metals, U.S. Geological Survey Open-File Report, 96-362.

Huang, W. (2003). Heavy metal concentrations in the common benthic fishes caught from the coastal waters of Eastern Taiwan. Journal of Food and Drug Analysis, 2. (4): 324-330.

Kamaruzzaman, B.Y., Akbar, B., Jalal, K.C.A. and Shahbudin, S. (2010). Accumilation of metals in the gills of Tilapia fingerlings (Oreochromis niloticus) from invitro toxicology study. J. Fish. Aquat. Sci., 5(6):503-509.

Kotze, P., H.H. Du-Preez and J.H.J. Van Vuren (2006). Bioaccumulation of copper and Zinc in Oreochromis mossambicus and Clarias gariepinus, from the Olifants River, Mpumalanga, South Africa. Dept. of Zoology, Rand Afrikans University Press, Water SA, South Africa, 25(1): 0378-4738.

Martinez, C.B.R., Nagae, M.Y., Zaia, C.T.U. and Zaia, D.A.M. (2004). Acute morphological and physiological effects of lead in the neotropical fish, Prochilodus lineatus. Braz. J. Biol., 64(4):797-807.

Narges, B.A., Ahmad, S., Mohammadsedigh, M., Hossein, Z., Negin, S., and Zohreh, B.A. (2012). Non essential metals $(\mathrm{Cd} \& \mathrm{~Pb})$ accumulation and elimination in liver tissue of Juvenile milkfish after sublethal exposure. Ind. J. of Geo-Marine Sci., 41(5),412-417. 
Otitoloju, A.A. (2001). Joint action toxicity and bioaccumulation of heavy metals. Ph.D. Thesis. University of Lagos. 225.

Rademacher, D.J., Steinpreis, R.E. and Weber, D.N. (2003). Effects of dietary lead or dimercapto sussinic acid exposure on regional serotonin and serotonin metabolic content in rainbow trout (Oncorhynchus mykiss). Neurosci. Lett., 339:156-160

Rauf, A., Javed, M., and Ubaidullah, M. (2009). Heavy metal levels in three major carps (Catla catla, Labeo rohita and Cirrhinus mrigala) from the river Ravi, Pakistan. Pak. Vet. J., 29: 24-26.

Senthil, M.S., R. Karuppasamy, K. Poongodi and S. Puranesurin, (2008). Bioaccumulation Pattern of Zinc in Freshwater Fish Channapunctatus (Bloch) after chronic exposure. Turk. J. Fish. Aquat. Sci., 8: 55-59.

Spokas, E.G., Spur, W.B., Smith, H., Kemp, F.W., and Bogden, J.D. (2006). Tissue lead concentration during chronic exposure of Pimephales promelas (fathead minnow) to lead nitrate in aquarium water. Environ. Sci.Technol., 40: 6852-6858.

USEPA, (1976). Effects of exposure to heavy metals on selected fresh water fish: toxicity of copper, cadmium, chromium, and lead to eggs and fry of seven fish species. Environmental Research Laboratory, Office of Research and Development, Duluth, MN. 600/3-76-105.

USEPA, (2002). Methods for measuring the acute toxicity of effluents and receiving waters to freshwater and marine organisms, fifth edition, Washington D.C

Victor, K., Patience, A. and Oluwatoyin, J.A. (2012). Accumulation of lead in the tissues of fresh water catfish Clarias gariepinus wxposed to static nominal concentrations of lead nitrate. Aric. Biol. J. N. Am.,3(12),510-515.

Vinodhini, R., and Narayanan, M. (2008). Bioaccumulation of heavy metals in organs of freshwater fish Cyprinus carpio (Common carp). Int. J. Environ. Sci. Tech., 5 (2):179-182. 